\title{
Analysis of Recovery from Fire Risk in Industry and Commerce
}

\author{
by Eric W. Marchant*
}

\begin{abstract}
This paper reviews briefly the concepts of total loss control and some of the factors of business interruption and consequential loss. The various features of these concepts are recognised as contributors to the objective: "Efficient productivity with greater profitability" (Fletcher and Douglas, 1971(a)). Any interruption to business because of fire, or any other agency, is regarded as a failure of one, or more aspects of loss control. Case studies are presented that attempt to identify failures of loss control and it is clear that no single feature of a loss control system is wholly responsible for a failure although it is clear that single features can be a major causal agency.

Complete recovery from the effects of fire on a business, may or may not, be achieved. The probability of successful recovery is not a direct function of the magnitude of the loss but more a complex combination of factors. The principal factors appear to be the financial status of the fire hit company; the ability of the management team to respond to a crisis; the quality of professional advice available to the owner; and the attitude of the insurance company to the fire hit enterprise.
\end{abstract}

\section{Introduction}

The techniques of fire loss reduction have emphasised the technological aspects of fire prevention; fire protection and fire suppression, each aspect recognising that a failure may occur in the loss reduction capability of the preceding aspect. There is a long history of experience in matching identified risk with appropriate technology, especially in the insurance industry. The effectiveness of these matches between risk and the protective technology is shown to be good but the real financial losses due to fire continue to increase. One reason for

* Director, Unit of Fire Safety Engineering, University of Edinburgh, United Kingdom. Paper presented of the Third Management of Risk in Engineering Seminar, sponsored by the Geneva Association, Glasgow, 17-19 April 1985. 
this continuing increase may be that the careful matching of risk to loss reducing technology occurs when new buildings, or plant, are proposed and when major changes to an enterprise is undertaken. The majority of the existing stock of industrial and commercial buildings may not be reassessed for many years during which time many subtle changes may have occurred. These "unnoticed" changes could change the probable maximum loss significantly. The adequacy and state of the technological systems at the time of a fire is well recorded and it is shown that, for some good reason, systems may not be operable at the time of the fire but no compensatory measures were introduced to maintain the appropriate level of protection.

Naturally, the key features of fire loss control are identification, assessment and mitigation of the hazard. The reinstatement of an enterprise after a fire is recognised as a need because of the operation of insurance policies for consequential loss, that is for losses that are consequent on a hazard being manifest even providing that adequate prevention, protection and extinguishment systems are in operation. The intention of consequential loss insurance is to enable the fire hit company to recover to its operating state before the fire. To estimate the scale of consequential loss, before the fire event, it is necessary to carry out a business interruption survey. The results of such a survey would enable a positive plan for post-fire recovery to be generated. Such a plan would be likely to define those parts of a production plant and loss sensitive features of a building that are critical to continuing operation and would also define the relevant responsibilities of company management and their professional advisers.

To be able to carry out a business interruption survey and to predict the likely consequences a knowledge of the factors that cause success or failure of a company to recover from the effects of fire would be useful.

Unfortunately, the techniques and methods of surveying for business interruption are not well developed (Lees, 1980/1983 (b)) and the quantity of literature on the problems of post-fire recovery is very small. It is hoped that this paper will be a contribution to that literature.

\section{Risk}

Accepting that a principal objective of business is to maintain efficient productivity so that continuing profitability is achieved, recognition has to be given to the many incipient risks that surround a business operation. Any one of these risks, if manifest, could reduce or eliminate production and profit. The risks that surround a business activity have been classified (Bannister, 1976) and these classes are listed in Table 1.

All of the nine risk classes are components of loss control and the fire threat is part of class one - the risk of physical loss and/or damage to property. An important feature of this class of risk is that it can be managed and it is capable of quantitative and qualitative assessment and is, therefore, insurable.

Classes 1-5 are likely to be controlled within an enterprise but the remaining classes cannot be controlled by an individual management. However, changes in classes 6-9 need to be observed by management and, where appropriate, changes brought about in the activity of the enterprise to counter the observed changes or to takes advantage of changes to increase productivity and/or profitability. It is clear that the actual occurrence of any threat component of a risk class will influence the viability of a company. 
Table 1: Classification of risk (Threat)

\begin{tabular}{|c|c|c|}
\hline Risk & $\begin{array}{l}\text { Probable consequence if } \\
\text { risk is manifested }\end{array}$ & $\begin{array}{l}\text { Level of management } \\
\text { control }\end{array}$ \\
\hline $\begin{array}{l}\text { 1. Physical loss or damage } \\
\text { to property }\end{array}$ & Injury/Death & \\
\hline 2. Liability & $\begin{array}{l}\text { Suits from Customers/ } \\
\text { Employees/Public }\end{array}$ & $\begin{array}{l}\text { Potentially at least } \\
\text { partially manageable } \\
\text { (and insurable) }\end{array}$ \\
\hline 3. Business interruption & $\begin{array}{l}\text { Loss of earnings from } \\
\text { physical or other loss }\end{array}$ & \\
\hline 4. Management & $\begin{array}{l}\text { Poor planning, control, } \\
\text { staff selection, etc. }\end{array}$ & $\begin{array}{l}\text { Directly controllable } \\
\text { by Management }\end{array}$ \\
\hline $\begin{array}{l}\text { 5. Wastage } \\
-\ldots-\ldots-\ldots-\cdots\end{array}$ & $\begin{array}{l}\text { Poor packaging, stock } \\
\text { control, deterioration, } \\
\text { corrosion, etc. }\end{array}$ & - \\
\hline 6. Technological & $\begin{array}{l}\text { Change reducing demand } \\
\text { or profit, failure of } \\
\text { new technology }\end{array}$ & $\begin{array}{l}\text { Not directly } \\
\text { controllable by } \\
\text { Management }\end{array}$ \\
\hline 7. Social & $\begin{array}{l}\text { Change in habit, less } \\
\text { product demand, more } \\
\text { vandalism }\end{array}$ & $\begin{array}{l}\text { May have positive } \\
\text { or negative effect }\end{array}$ \\
\hline 8. Political & $\begin{array}{l}\text { Government legislation. } \\
\text { Other pressure groups. } \\
\text { (especially inflation, } \\
\text { Foreign exchange risk) }\end{array}$ & $\begin{array}{l}\text { Manageable to greater or } \\
\text { lesser extent }\end{array}$ \\
\hline 9. Physical Environment & $\begin{array}{l}\text { Climate, Depletion of } \\
\text { Resources }\end{array}$ & \\
\hline
\end{tabular}

\section{Loss control}

Loss control is concerned with those features of the business environment which could reduce viability and the areas that can affect an enterprise adversely have been listed (Fletcher and Douglas, 1971) as is:

(1) Business interruption; (2) injury; (3) property damage; (4) fire; (5) security; (6) health and hygiene; (7) pollution; and (8) product liability.

An examination of these areas needs to be treated by the following four steps:

(1) identification - of possible loss producing situations;

(2) measurement - of loss potential; 
(3) selection - of methods to minimise loss; and

(4) implementation - of loss control methods within the organization.

The areas of interest in loss control cannot be considered in isolation but as a set of interactive influences on the viability of a company. For example: the occurrence of a fire could breach security, cause injury and property damage, cause an immediate interruption to business, and through the pollution created the consequences of fire could be a medium term threat to health and hygiene. However, a fire may reduce product liability as no product will be produced but this would not be good for the objective of efficient production and continuing profitability.

In fire loss management six treatment steps have been identified (Woolhead, 1976?). These six steps include the four noted above and introduce: Allocation of priorities to the selected methods; and the development of comprehensive contingency plans. The purpose of these plans are defined as "to mitigate losses involved and to resume or continue business activity as effectively and as profitably as possible".

Contingency planning, or planning for emergencies, is described as a prominent aspect of loss prevention and applies equally to the production location and in transportation (Lees, F.P. $1980 / 1983$ (a)).

\section{Business interruption}

Perhaps the most important area of loss control is business interruption. This area has been further characterised (Fletcher and Douglas, 1971 (b)) by the possible effects of business interruption. These are listed as: Money commitment (capital, operating expense, litigation); Time commitment (idle labour, idle equipment); Reduced production (requires alternative courses of action, supplies and transportation); Rerun or rework products; and lost sales due to delay and/or alienation of customer. Each of these factors, except litigation, play some part in the case studies described in this paper although in different combinations and with different levels of importance. To reduce the maximum potential impact of business interruption a principal feature of the various companies that survived a fire successfully is the flexibility of action that can be used to avoid a total stoppage of business.

\section{Fire control}

In the development of a loss control programme fire control becomes an essential component because of the potential of a fire to create direct and complex consequential losses. Naturally, if fires can be prevented, or if not prevented they are controlled effectively to an "acceptable level", a significant reduction in loss potential can be achieved. Fire control has been divided into two major components: Prevention and Extinguishment (Fletcher and Douglas, $1971(\mathrm{c})$ ). Each of these components are described by a number of sub-components as listed and summarised below (Table 2).

The list of sub-components in Table 2 does not give a complete sequence of actions that may be needed to reduce loss from fire but they do emphasise the first two important stages in the sequence of fire growth. The emphasis within the component "Prevention" is that all 


\section{Prevention}

Sub-Component Note of description

DESIGN

MAINTENANCE

PROCEDURES

INSPECTION
Examination of the manufacturing process for inherent ignition possibilities. Match value per unit volume to techniques of detection and control.

Spatial configuration and materials of building.

Programmed maintenance of machines to reduce probability of ignition. Care of all installed fire safety systems.

Action plans for fire control. Supervising systems for hot work.

Programme of inspection of all processes and part-processes where ignition is possible.

Inspection or work practice and procedures especially where a change could alter fire risk.

\section{Extinguishment}

Sub-component

Note of description

ORGANIZATION

EQUIPMENT

KNOWLEDGE

TRAINING
Personnel awareness and responsibility. Surveillance of all spaces important. Fire control function should be part of Loss Control Department.

Adequacy of fire control equipment, number, location, type, up-todate.

Adequacy of fire control notices, dissemination of information about risks, knowledge of appropriate techniques.

Depth of training depends on scale of organization. In any organization some people should be trained for effective fire control. Training should be a regular feature of a fire control programme.

operations, procedures and systems that make up a productive industry should be identified, inspected, assessed and treated to reduce the potential loss. If prevention fails then the early extinguishment of a fire becomes a proper emphasis. Within the component "Extinguishment" the descriptions emphasise vigilance and "first aid firefighting". This approach accepts a probability of failure of prevention but is limited by not exploring the problems that would be faced by management if early fire control was not achieved.

A list of loss control strategies has been published (Anon, 1984) which follows the potential failure sequence by outlining possible strategies that could interrupt the failure sequence successfully. (This sequence has been called Haddon's ten strategies). 
1. Prevent creation of hazard.

2. Reduce amount of hazard that could be released.

3. Prevent release of existing hazard.

4. Modify spatial distribution or release of hazard from its source.

5. Separate, in time and/or space, hazard from exposed.

6. Separate hazard and exposed by interposition of a barrier.

7. Modify basic qualities of hazard.

8. Make the exposed more resistant to hazard.

9. Counter the damage done.

10. Stabilise, repair, rehabilitate or replace the object of damage.

The list of strategies in Table 3 is clearly intended to embrace a wide range of technological problems and its logic has a relevance to fire loss control and to the particular aspect of postfire recovery especially in the latter stages of countering the damage done and the stabilisation, rehabilitation and replacement actions that may be required to control overall loss.

\section{Consequential loss}

The manifestation of a risk, or threat, always results in a loss of some value. The effect of the loss on a company is not related directly to the value but is related to the impact of the loss on the productive capacity of the system that has suffered. Degrees of severity have been defined simply (Haller, 1977) and their impact on a system described. This is summarised in Table 4.

Table 4: Degrees of risk severity

\begin{tabular}{ll}
\hline Risk manifest & Effect on system \\
\hline Catastrophic risk & Destroys system. \\
Large risk & \\
Medium risk & Causes particular goals or expectations to be changed. \\
Small risk & Nuisance risk
\end{tabular}




\section{Consequential loss to the economy}

The impact of loss on different systems has been studies (Kingston et al, 1977). Eightyfive firms that has suffered a fire between 1969 and 1973 were selected for detailed investigation the principal objective of which was the assessment of the impact of fire losses in industry and commerce on the national economy. A broad conclusion was that the majority of fires, in the sample, do not create any direct consequential loss to the economy although sections of the construction and engineering industries may need to devote resources to the reinstatement of fire-hit firms, resources that could otherwise be used in new construction. The impact of this use or resources on the national economy was judged to be negligible. In a discussion of the results of the study (Home Office, 1980) it was noted that the bulk of consequential losses occur in less than 2 per cent of the fires causing over $£ 25,000$ direct loss. This suggested that the impact on the economy is concentrated on a very small fraction of fires. For example fires in electricity generating systems could have significant long term effects on the economy but because the low frequency of significant fires (once in 5 years) and the potential for redistribution of electricity around the country (together with a probable excess of capacity compared with demand) even these fires are unlikely to have a significant medium or longterm effect on the economy. The criteria used to evaluate consequential loss to the economy (with their associated comments) are summarised in Table 5 (Home Office, 1980).

Table 5: Evaluation criteria for consequential loss to the economy

Criteria Comment

Sales lost by fire-hit company pass to other UK companies.

Sales lost to foreign competition.

Sales lost altogether.

Extra costs of working involving transport, hire of equipment, conversion of premises, power, extra materials (ie linked to additional consumption of resources).

Extra costs of working involving overtime. buying in from UK, renting of temporary premises.

Efficiency changes (loss or gain).
No loss to economy (sales transferred within economy).

Full value of lost sales is a cost to the economy in foreign currency.

Tax on profit element is loss to economy.

Loss to economy is full cost.

Loss to economy is zero (income transfer within economy).

Full cost or benefit is a consequential effect on economy. 
"The main reasons for the absence of economic losses in many cases is that spare capacity in the UK economy permits sales lost to be made good by UK competitors, or the fire-hit firm to maintain sales by buying in from other UK sources, or working overtime. In fact, most industries operate with sufficient flexibilty to have such effective spare capacity at all times. Those industries which attain a true full capacity operating condition are those higher technology, continuous process industries which have been identified as prone to high consequential losses to the economy when fires occur within them. In services, the degree of competition and the inherently flexible nature of working in most of the sector implies that high consequential losses to the economy will not occur, and the same is true for much of manufacturing industry. In such industries, extra costs of working are a more likely cause of consequential loss to the economy than other factors related to loss of sales. Cases were even identified in the study where firms were able to improve their efficiency following a fire, resulting in gains to the national economy." (Home Office, 1980 (a)).

Using the same criteria as listed in Table 5 but applying them to the effect on a fire-hit company the comments would be very different and it is stressed (Home Office, 1980 (b)) that the study was concerned with the effect of consequential loss on the economy and not the effect on the fire-hit firm. In fact the review pointed out quite clearly that manufacturing industry suffered disproportionate losses from fire when compared with other sectors of the economy and included a recommandation that a feasibility study should be initiated to examine the potential for the development of a self-financing fire risk management service for the high loss sectors of industry (Home Office, 1980 (c)), namely the small to medium sized firms especially those in chemical and electrical engineering.

An interesting feature in the report (Kingston et al, 1977) is the relative losses with respect to the trade cycle. It was found that 1973 was, and effectively, a year of full production when consequential loss could be regarded as at a peak. Table 6 summarises some of the results.

Table 6: Consequential loss to the economy and the business cycle (Kingston et al; 1977)

\begin{tabular}{|c|c|c|}
\hline \multirow[t]{2}{*}{ Sector } & \multicolumn{2}{|c|}{$\begin{array}{c}\text { Relative loss per incident } \\
(1969-1973)\end{array}$} \\
\hline & off peak years & peak year \\
\hline Manufacturing excluding chemicals & 0.49 & 2.34 \\
\hline Services & 0.62 & 3.50 \\
\hline----------- & $-\cdots-\cdots$ & $-\ldots$ \\
\hline Manufacturing excluding chemicals & 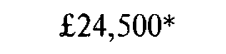 & $\mathfrak{1} 116,200$ \\
\hline Services & $\mathfrak{£} 1,000$ & $\mathfrak{£} 5,000$ \\
\hline
\end{tabular}

\footnotetext{
* Calculated cost per incident at 1971 prices.
} 


\section{Consequential loss to a company}

The estimates in Table 6 refer to differences between trading years but the trading cycle of a single company may be complete in one year especially for those companies whose products are subject to seasonal demand, for example the hotel industry. The time in the trading cycle when the fire occurs is unlikely to affect the direct losses but is likely to have a considerable impact on consequential loss. For example, a minor fire occurring at a low point in the annual trading cycle may result in no loss over the trading year or may even result in a gain because of opportunities that may be taken to improve facilities during the period of reinstatement. Conversely a total failure may result.

The potential sources of consequential loss to a company are many and varied but the impact of loss will depend on whether the specific company is independent or inter-dependent on other companies. (Marchant and Henesy, 1979/1980). The inter-dependent company is one that relies on other companies as suppliers and/or customers. Such a company may not be a critical supplier therefore other similar companies could take a large proportion of market share which may, or may not be regained by the fire-hit company. Alternatively, the company my be part of a larger group of companies and its facilities are duplicated elsewhere in the group. However, if each company in the group is critical to the production of the final product, the large relative losses are likely and could be caused by the manifestation of a "nuisance" risk at a critical location causing catastrophic consequences to a group.

The independent company, trading in the open market for suppliers and customers, with no duplicate facilities has a greater relative loss potential compared with a company in a group. It has been noted that two characteristics of the operation may have important influences on post-fire recovery: 1) the precision of the final work piece, and 2) the general efficiency of the company, especially the efficiency of space use. The greater the precision required the greater the possible consequential loss; the greater the flexibility of space usage the possible loss will be relatively lower. (Marchant and Henesy, 1979/80).

The detailed factors that influence probable consequential loss are difficult to define but three broad factors are important: 1) Susceptibility to interruption; 2) Potential speed of recovery; and 3) Assistance towards recovery. Some of the features of each factor are listed below.

\section{1) Susceptibility to interruption}

Type of materials used, availability of materials, single-source, multi-source.

Type of process: line or batch process; single-line, duplicated or multi-lines.

\section{2) Potential speed of recovery}

Reinstatement of building: legal, technical, social factors;

Availability of supplies: seasonal, importation factors;

Machinery: down time, replacement time: custom made, easily available;

Market situation: competitors, trade cycle. 


\section{3) Assistance towards recovery}

Sub-contract work orders;

Cash flow; insurance; and

Availability of Professional Advisers.

\section{Planning for post fire recovery}

The features listed above could form part of a post-fire contingency plan. Such a plan is regarded as important if a speedy return to pre-fire operation is intended. A published case study (Sharrock, 1975), about a petrochemical plant which caught fire during the commissioning stage, states that a team of engineers needed four weeks to produce a plan for reinstatement - a significant contribution to the total down time. In this case no significant loss occurred in the short term because of a fortuitous up-turn in market demand during the first trading year.

Planning for loss control in general and for post-fire recovery in particular is a complex balance of many factors that contribute to potential loss. The identification and quantification of potential sources of failure can be balanced by the provision of adequate and appropriate measures for fire prevention and fire protection to protect property (Fletcher and Douglas, 1971; Maynes, 1983).As a consequence of protecting property aspects of such assets as people, productivity, profitability, and future prospects are protected also (Woolhead, 1984). The complex features of contingency plans help to reduce the sensitivity of a business to loss of viability if a risk is manifest (Fletcher and Douglas, 1971). In this context it has been made clear (Bawcutt, 1982) that physical improvements to risk are very unlikely to eliminate the overall exposure to loss, and that a contingency plan can help to reduce the time needed to restore full production. A number of actions were given that would becomes features of a contingency plan. These are listed in Table 7 with some comment on responsibility for action.

Table 7: Some elements of contingency planning

Action Responsibility

Obtain outline planning permission for replacement

Designate some plant to "standby" status

Multi source suppliers

Analyse complete plant for operational sentivity

Carry out a "What if?" analysis of whole operation
Administration/Design

Technical

Administrative/Technical

Technical

Technical 
During the analysis of operations it has been suggested that there are three specific areas of enquiry (Damico, 1983) that could be pursued pre- or post-fire.

1) What volume of sales, up to the limit of loss production, was (maybe) irretrievably lost as a result of the production interruption?

2) What savings were (maybe) realized in terms of raw materials, employee lay offs, and reduced running costs (e.g. fuel, rates)?

3) What effort did (could) the insured make to minimize the effect of loss, and to what result?

Recently (de Moulins, 1984) the responsibility for facilitating post-fire recovery, as well as many other aspects of fire safety, was regarded as being that of "the manager". But management may need to become more knowledgeable about risk and the consequences of its manifestation as rules and regulations, legislation or insurance, need to be conceptualised before application to a particular problem and it should be understood that too much protection can be counter productive both practically and financially.

An overall sequence of loss reduction features and the general consequences of their failure has been developed (Marchant, 1984). Although the sequence, presented as Table 8, is concerned with people and commercial buildings it can be related to the problems of industry. At each stage of the fire-failure sequence greater costs are involved to compensate for the

Table 8: the design, fire, loss reduction and failure consequence sequence

\begin{tabular}{|c|c|c|c|}
\hline Design stage & $\begin{array}{l}\text { Fire } \\
\text { development } \\
\text { sequence }\end{array}$ & $\begin{array}{l}\text { Fire safety component/loss } \\
\text { reduction factor }\end{array}$ & $\begin{array}{l}\text { Consequence of } \\
\text { component failure }\end{array}$ \\
\hline 1 Inception & Pre-ignition & Education & Fire incidence \\
\hline 2 Spatial activity & Ignition & $\begin{array}{l}\text { Identification of potential } \\
\text { ignition sources }\end{array}$ & Energy release \\
\hline 3 Material selection & Development & $\begin{array}{l}\text { Material properties. } \\
\text { Detection systems } \\
\text { auto-suppression. }\end{array}$ & $\begin{array}{l}\text { Toxic gases, smoke, } \\
\text { heat. }\end{array}$ \\
\hline 4 Spatial aesthetics & (Continued) & Escape route design & $\begin{array}{l}\text { Non-escape injury, } \\
\text { death. }\end{array}$ \\
\hline 5 Spatial relationships & (Continued) & Smoke control & $\begin{array}{l}\text { Smoke } \\
\text { travel/immersion. }\end{array}$ \\
\hline $\begin{array}{l}6 \text { Spatial } \\
\text { interconnection }\end{array}$ & (Continued) & $\begin{array}{l}\text { Manual/auto suppression; } \\
\text { passive fire control. }\end{array}$ & Fire spread \\
\hline $\begin{array}{l}7 \text { Materials choice } \\
\text { Barrier performance }\end{array}$ & Flashover & $\begin{array}{l}\text { Fire design; constructional } \\
\text { barriers, thermal insulation; } \\
\text { auto-suppression. }\end{array}$ & $\begin{array}{l}\text { Maximumtemperature, } \\
\text { multiple deaths. }\end{array}$ \\
\hline 8 Barrier performance & $\begin{array}{l}\text { Spread to } \\
\text { fuel limit }\end{array}$ & $\begin{array}{l}\text { Junction details; } \\
\text { structural performance; } \\
\text { constructional design. }\end{array}$ & $\begin{array}{l}\text { Building damage; } \\
\text { collapse. }\end{array}$ \\
\hline 9 Materials selection & Decay & $\begin{array}{l}\text { Construction; structural } \\
\text { and systems design. }\end{array}$ & $\begin{array}{l}\text { No building; } \\
\text { residual collapse. }\end{array}$ \\
\hline $\begin{array}{l}10 \text { Pre-planning for } \\
\text { post-fire recovery }\end{array}$ & Recovery & $\begin{array}{l}\text { Prevention, future } \\
\text { planning, accommodation } \\
\text { of losses. Insurance. }\end{array}$ & $\begin{array}{l}\text { No facility; } \\
\text { no activity. }\end{array}$ \\
\hline
\end{tabular}


consequences of failure and this could be important in the development of a loss control contingency plan. It is clear from the sequence that many simple, and apparently loss independent, decisions on design and construction can affect the magnitude of potential loss.

The design of buildings can have a significant influence on actual loss. Principal features are the size, shape and relationships of spaces within a building, or a complex of buildings and the constructional design of the building(s). Smaller individual spaces and the integrity and stability of the barriers between the spaces are well know methods for reducing the expected maximum loss (Aqua Group, 1984) and the degree of protection afforded is reflected in lower insurance premiums. However, it is accepted commonly that "the insurance company" will be able to assist the owner, production engineer and designer to achieve an industrial or commercial enterprise that is protected from fire losses at an economical and cost-effective level and that the principal objective of post-fire recovery, the rapid regain of full productivity and profitability, can be achieved easily.

\section{Case studies}

The eight case studies that follow include two from recently published literature and six that were selected from the records of the Lothian and Borders Fire Brigade (S.E. Scotland). In the latter group information from records was supplemented by visits to the site and interviews with management and/or owners of the business. (Maynes, 1983).

Case study 1 - Electronic data processing equipment (Larsen, 1984)

(a) Nature of process

Data processing, in-house, for a large company and the preparation of data processing equipment for customers.

(b) Nature of premises

The computer room, of about $160 \mathrm{~m}^{2}$ in area, had a suspended ceiling of rockwool panels and a raised floor, about $500 \mathrm{~mm}$ above the structural floor, of removable linoleum covered chip-board panels. The room contained a unit air conditioning system supplying air at $23^{\circ} \mathrm{C}$ and $55 \%$ relative humidity to the floor cavity and extracting air at high level in the computer room. The room contained a large processor system used for internal data processing and demonstration to customers; a smaller new processor system for supply to a customer; numerous shelves of magnetic tapes and terminals; and the air conditioning system.

\section{(c) Character of loss}

The fire began in the line printer associated with the large processor system. The operator on duty did not know the shut down procedure but telephoned from the next room for instructions. He could not return into the room because of heavy smoke. Then the fire brigade was called and arrived promptly. Subsequently a staff member, in breathing apparatus entered the smoke filled room and switched off the main power. The fire brigade then entered the room with $\mathrm{CO}_{2}$ extinguishers and two high pressure jets. The fire in the line printer was extinguished quickly and the smoke cleared rapidly by breaking some floor to ceiling glazing. From the first smell of smoke to extinguishment only 15 minutes had elapsed. 
In the line printer a short circuit had ignited paper dust which burned vigorously aided by the high ventilation rate through the machine. This caused a bundle of PVC covered cables to ignite creating the dense smoke and hydrochloric acid gas which had spread over the whole room.

\section{(d) Recovery characteristics}

Measurements of chloride concentration revealed deposits of 20-50 micrograms per $\mathrm{cm}^{2}$ on various items of equipment, far above the corrosion risk limit of 8 micrograms per $\mathrm{cm}^{2}$. Three insurance companies were involved, the division of liability being: (1) the EDP systems; (2) the other contents of the room; and (3) the building. It was agreed to recondition the processor for the customer; all magnetic tapes were copied; and commencement of reconstruction to the damage to the fabric of the building, was carried out in one day. The complete reconditioning of the room was completed in two weeks. A new large processor was installed and operational after four weeks. The reconditioned smaller processor was available to the customer after 5 weeks.

The main features of this recovery were: (a) rapidity of fire control; (b) immediate response by three insurance companies; and (c) the availability of technical expertise to recondition EDP equipment rapidly and economically.

Case study 2 - Manufacture of fibreboard (Kalt, 1984)

(a) Nature of process

The company produces woodfibre boards. The process is mainly a wet process but in the final stages the boards are dried at $160^{\circ} \mathrm{C}$ for 2 hours. Operation is on a 3 shift basis (i.e. 24 hours) and about 80 people are employed. A number of small fires occurred regularly, usually smouldering fires, caused by stones and metal objects in the woodfibre mixture.

\section{(b) Nature of premises}

The buildings had grown up over a period of 40 years and a variety of constructional systems had been used. The total complex covered an area greater than $10,200 \mathrm{~m}^{2}$. Although the company exercised some care it was not very systematic and the buildings had grown without any thought about fire problems. Most of the buildings abutted one another and the whole had an insured value of 50,000,000 Swiss Francs (1980). In the construction of various buildings much wood had been used and large quantities of wood dust had accummulated.

\section{(c) Character of loss}

A smouldering fire in a floor cavity seems to have developed into a flaming fire and was discovered at about $4.00 \mathrm{a} . \mathrm{m}$. The fire spread at "the speed of a scampering mouse". The fire damaged or destroyed more than $2,200 \mathrm{~m}^{2}$ of the buildings and some compartmentation stopped the further spread of the fire but fire control was hampered by lack of water. Eventually water was pumped from a nearby river for firefighting. The direct cost of damage was estimated at 9,000,000 Swiss Francs (1980), a significant fraction of the insured value. 
The closure of the firm was a possibility because easily ignited woodfibre board was not a popular construction material! Therefore a real danger of loss of market share existed.

Replacement of some special machines was difficult but the plant was back in full production four days after the fire!

(d) Recovery characteristics

Although a rapid return to production was made possible some difficulties with insurance were experienced. A major consequence of the fire was the improvements made to the various fire precautions. These are listed below.

1. The new part of the building was constructed using "a better system".

2. Thirty doorways were bricked-up thus improving compartementation.

3. The necessary doorways were provided with two sets of doors.

4. Separation was achieved between production and storage areas.

5. A sprinkler system was installed - the water supply system was more expensive than the sprinkler system!

6. Hydrants and hydraulic hose reels were installed - with a pumped river water supply.

7. Dust extractors were installed.

8. Infra-red flame detectors were installed in the drying area.

9. Signs and emergency lighting were installed.

10. The telephone system was adapted for emergency use.

11. Major hazard spaces were enclosed with F90 construction.

12. All pipe networks re-organized.

13. Extra spare parts for machines were stored.

14. Inventories of all contents of all spaces were made.

15. A security firm was engaged to carry out night-patrols.

16. Company fire fighting team was strengthened.

17. A training programme for all staff was instituted.

18. Annual fire audits were arranged.

19. "No smoking" rules were introduced in "sensitive" areas with a penalty for contravention of instant dismissal.

A new safety consciousness was instilled at all levels in the firm and as a result of all improvements the risk was lowered to achieve a reasonable risk/premium ratio.

\section{Case study 3 - Spinners and dyers of woollen yarn}

\section{(a) Nature of process}

The fire-hit firm is a substantial subsidiary of a large, international textile group which brings together about thirty companies whose activities range from animal husbandry to the retailing of fashion knitwear. The firm controls four woollen yarn spinning factories which 
produce yarn for supply to other group companies for garment manufacture and for supply to customers outside the group. Each of the four factories produce yarns for different end-purposes. The particular fire-affected factory produces yarns for clothing only and its production represented about $50 \%$ of the production of similar yarns in the total of the four factories. In addition to manufacturing facilities the fire affected site houses the company's administrative offices, stores for raw materials and the finished product, a staff canteen and a quality control laboratory.

The raw materials include wool (3-4 days supply), dyes (up to 3 weeks supply), and the finished product (yarn) (up two weeks output being stored). The wool is supplied entirely from within the group and is replaceable readily. Dyes supplied from outside the group may take up to two weeks to replace. Production is in a line process and the quantity produced follows a cycle influenced by seasons of the year and fashion trends, but the company is able to work at near full capacity most of the year. A three shift mode of working was operated and the machine utilisation is at full capacity during the trade-cycle peak and production space is fully utilised continuously. No spare capacity was built into the production process and any flexibility would only be the result of a decline in demand. Maintenance staff provide a 24 hours a day service and major damage to any machinery could result in a down time of up to 3 months. Losses due to any down-time are covered by business interruption insurance.

(b) Nature of premises

The site included a complex of buildings most of which were constructed externally with stone or brickwork non-combustible walls. Internally, the floors and staircases were constructed in timber.

\section{(c) Character of loss}

The fire was set in one of two adjoining unsprinklered warehouses of finished product. Before the fire could be controlled it had destroyed most of the internal wooden construction being two upper floors and associated staircases and the roof. Fire spread across the roof to the roofs of an adjoining staff canteen and the second warehouse. Initially, the warehouse first affected was considered suitable for re-instatement but during the clearance of debris, part of one wall collapsed and a decision was made to demolish the warehouse with the agreement of the insurance company.

The fire occurred in January which corresponded to a period of low demand for the finished yarn product therefore the quantity of on-site storage was less than would have been the case at other times in the year. The fire destroyed approximately one week's output of yarn and a small quality control laboratory including all samples and records which was contained within the warehouse. Electrical power supplies to part of the complex was affected also.

\section{(d) Recovery characteristics}

The fire caused no more than a "very slight ripple" through the chain of manufacture within the total group of companies. There was no loss of market and customers whose supplies were destroyed were content to accept delays in delivery of their orders.

A very rapid recovery was made by the company and some of the feat ures of this recovery are listed below. 
1. The firm's own electricians restored electrical power to all areas before the commencement of the next shift.

2. Good compartmentation between adjoining buildings stopped any major fire spread.

3. Company workers commenced salvage of finished goods stocks in the second warehouse, not much affected by fire, and the quantity salvaged accounted for $50 \%$ of the total production stock at the time of the fire.

4. The fire occurred at a fortuitous time in the trade cycle.

5. No raw materials or dyes had been lost in the fire.

6. Storage space was available for rent in the immediate area of the factory and the cost of rental was covered by insurance.

7. The quality control function was maintained by sending work to the control laboratories at the other three factories.

8. The size of the group was sufficient to secure good financial backing to initiate a costly recovery action before negotiations with insurers.

In summary, the recovery of the production capability took less than $1 \mathrm{shift}$, production was back to normal within five weeks, with limited use of overtime, and office work was not interrupted.

The company had no contingency plans in case of fire relying on the flexibility of management to respond to a crisis. Fortunately, this was justified in the event. The loss of quality control records meant that an increased liability for products had to be accepted and any claims may not be insured. As the company stored very limited quantities of raw materials and finished products this increase to the company's potential for rapid recovery from a major fire since stock losses are limited by practice to a pre-determined maximum.

\section{Case study 4 - Distillery}

\section{(a) Nature of process}

This company produces grain spirit for supply to blenders. Established as a co-operative, its board of directors include a representative from each customer company.

The basic steps in the production of distilled spirit are mashing, fermentation, and distillation. This is followed by several years of storage so that the spirit matures. In the process very large volumes of steam are required to provide energy for the production process, particularly for the distillation stage. Steam was supplied from either two oil-fired boilers operating together or from a bank of four coal-fired boilers. The dual source of steam was due to a change in fuel prices the oil-fired boilers being a recent installation and the retention of the other boilers gave some redundancy for steam production.

The whole production facility is located at one site which is surrounded by roads, railway lines and other buildings. Company warehouses are located on its production site and at three other locations.

\section{(b) Nature of premises}

Each of the buildings on the production site have solid heavy brickwork construction walls but timber floors. The oil feed to the boilers was pre-heated and both heating and 
pumping of oil occurred inside a small $(3 \times 3 \mathrm{~m})$ pump house outside the bund wall surrounding the oil storage tanks. The pump house was basically a reinforced concrete cube but had only a light timber, sliding door for its entrance.

\section{(c) Character of loss}

The fire is suspected to have originated due to an electrical fault in the $35 \mathrm{~kW}$ electric oil heater in the pump house. This was first recognised by a loss of steam pressure in part of the plant. On investigation, flames were noticed breaking through the light timber door to the pump house. The fire was fuelled continually by oil still flowing from the storage tanks into the pump house. Although a break-glass alarm was activated this was not linked directly to the fire brigade so some delay in their arrival was caused. However, soon after the arrival of the fire brigade the fire was extinguished. Damage was restricted to the interior of the pump house, its door and $2 \mathrm{~m}$ of metal encased lagging on the oil ring main. Electric pumps and associated wiring and control valves were damaged beyond repair in the pump house. However, the electric heaters were found subsequently to be undamaged and serviceable.

\section{(d) Recovery characteristics}

The oil-fired boilers were out of commission but because coal-fired boilers were still serviceable steam supplies were regained rapidly. The company's own maintenance men carried out electrical repairs so that power was back to the pump house within 12 hours. The oil pumps were readily available "off the shelf" and were supplied within 24 hours and installed. This availability was a consequence of a previous failure after which, where it was possible, all pumps and valves were of a common pattern.

Other features of this company's operation that reduced the impact of the loss was that they had a very long production cycle therefore any minor event could be absorbed within this time scale of years.

The company did not have a formal contingency plan but many of their logical decisions contribute towards the lack of impact of any business interruption. For example, customer's orders are divided and stored in separate warehouses; raw materials can be obtained from different sources; standardisation of equipment facilitated interchangibility of parts during modification and repair; and emergency shut-down procedures for the distillation plant were well understood.

As a result of the fire some additional fire precautions were instituted. These were:

1. Detectors to be installed in the pump house,

2. More frequent visits to the pump house by the staff,

3. A more substantial door to be placed at the entrance to the pump house, and

4. The institution of a more positive method of calling the fire brigade.

Because of the practice of risk management within this company very little effect will be shown to their customers of any minor event such as a small controlled fire. However, the fire did highlight some deficiencies in their fire defence system and improvements have been made. 


\section{Case study 5 - Foundry - Light Engineering works}

\section{(a) Nature of process}

This company is an independent, privately owned business which employs 80 persons. Its activities include: high quality metal casting and general foundry work; architectural metalwork; metal engraving and machining; and investment casting. The company has no trade cycle and at the time of the fire the company was working at full capacity. Insurance held by the company covered the building and its contents, loss of profits and maintenance of wages. The insurers had been very helpful previous to the fire, giving advice regarding fire prevention and housekeeping.

\section{(b) Nature of premises}

The building was about 40 years old and approximately $3,500 \mathrm{~m}^{2}$ in area, and this was divided into six roughly equal areas. All walls were of brickwork supporting a pitched roof which has a steel truss all covered with asbest os cement sheeting, except for two of the six sections which were covered with wooden boarding on wooden framing and an outside covering of waterproof felt. The internal brickwork walls did not provide fire compartmentation fully due to a member of openings several metres wide needed for easy access and ease of movement of work pieces between adjoining areas.

\section{(c) Character of loss}

The fire broke out in part of the building housing the foundry work. This part a wooden roof and framing across which the fire spread quickly destroying about $300 \mathrm{~m}^{2}$ of roof. In the fire area three furnaces and two drying ovens were put out of commission. Tools to the value of about $£ 10,000$ were damaged beyond repair and a large stock of moulding sand used in the casting process was rendered unusable but could be replaced readily. An electrical substation was damaged and cut off all power to both the factory building and the company's office block which was adjacent. These were no significant losses of finished product but several unique patterns were destroyed.

The fire involved $11 \%$ of the company's overall production area and this represented $1 / 3$ of its foundry work area. One consequence of this damage was that a single customer withdrew most of a large order and it was considered that that withdrawal could influence the placing of future work from that particular customer. Most of the company's activities were affected by the fire and some work was sub-contracted to other companies so that vital completion dates could be met. Unfortunately, the products made by the sub-contracted companies were below the appropriate standard and the work had to be replaced subsequently.

\section{(d) Recovery characteristics}

Temporary electrical supply was given to the office block and manufacturing areas not affected by the fire the day after. Within three days full electrical power had been re-connected. 
Although the staff was highly specialised they played a significant role in the clean up operations and the re-arrangement of machinery and equipment and stored items. Before reconstruction of the fire affected section of the factory production was re-started after re-organization of space use.

The loss of the drying ovens forced the company to look at alternative methods for setting moulds for castings. A chemical method was employed and this process proved to be quicker and less costly than the previous techniques.

The insurance company was of great assistance to the fire-hit firm both with advice and periodic payments.

The employment of a consultant engineer brought an expert on to the scene to assist the situation and to relieve management of the detailed tasks. This aided a speedy occupation of the fire affected areas.

Three weeks after the fire production was judged to be back to $85 \%$ of normal production.

Had the company developed a contingency plan it might have been possible to have identified the inappropriate use of space and have disposed of redundant mouldings and patterns that customers no longer needed. This review of space use might have helped the speedy relocation of machinery not affected by the fire. Such a plan may have indicated also the need for a standby generator to ensure power to the compressors since compressed air was a vital service to some of the finishing processes that had to be held up because of the loss of electrical power in the first few days after the fire.

\section{Case study 6 - Hotel}

(a) Nature of activity

A private owner had purchased a hotel some years before the fire and carried out significant renovation, restoration and decorative works. The hotel was located in a small village which had more hotels and public houses than its normal population warranted. Over three years the hotel had attracted a reasonable bar trade, a good functions trade, and a growing number of residential bookings. In addition contracts had been won to provide outside catering at a local tourist attraction. The hotel operated as a "free house" therefore it had no direct affiliation to any group or consortium of brewers or distillers. There was a definite peak of trading running from May to September during the year with good trading maintained until the beginning of January. Therefore the low part of the cycle was from mid January to April in each year.

\section{(b) Nature of premises}

The building consisted of a three-storey stone Victorian mansion house to which had been added a substantially wooden structure at ground level on one side which formed the function facilities. 


\section{(c) Character of loss}

The fire originated in the main kitchen on the ground floor spreading horizontally to the adjoining function rooms and vertically to involve several guest rooms. It continued into the roof void and the surrounding attic. This enabled the fire to spread rapidly horizontally through the roof space causing minor damage to other guest rooms in other parts of the buildings. Additional damage was caused by fire brigade activity because of the difficulty in ensuring that fire was extinguished completely. Only a small amount of contents were salvaged and the value of the loss was estimated at between $£ 300,000$ and $£ 350,000$ ( 1983 prices). Insurance cover was available for $£ 620,000$ but this included the buildings, their contents, and the value of personal effects of the owner who lived on the premises.

\section{(d) Recovery characteristics}

At the time of this study the hotel had not recovered from the fire and was still in the same state as it was during the fire some eight months earlier.

The following list outlines the main features of the non-recovery of this particular company.

1. The newly won contract for outside catering was lost.

2. The local bar trade was lost and competitors in the area regained their clientele.

3. The bank froze all business accounts pending investigation for more than 3 months. This resulted in non-payment of creditors which would indicate difficulties with supply after re-starting the business.

4. All function bookings were re-distributed to local competitors.

5. The holiday season bus trade was lost.

6. Residential bookings were given to a competitor.

7. All the staff lost their jobs.

Six months after the fire no money had been advanced by the insurance company and this may be partly to do with the fact that some doubt had been expressed about the origin of the fire and the forensic report was needed. Because of being unable to start positive recovery for at least six months after the fire there would be no summer trade in 1983 . The reconstruction period was estimated to be at least 1 year and a subsequent 5 years to regain lost business.

An important feature of this company was the fact that it was a "free house" and therefore had no big links, either commercially or financially, with any large group.

\section{Case study 7 - Restaurant}

\section{(a) Nature of activity}

A small stone building had been bought by a family some four years before the fire with the intention of converting the premises into a 12 bedroom residential hotel and restaurant. The first phase of this development was the construction of the restaurant on the ground floor. This was the development stage when the fire occurred. 
(b) Nature of premises

The building is about 80 years old and has solid stone walls with timber floors and a traditional timber and slated roof. The building is on three floors, ground, first and second floors. The affected part of the building was about $12 \mathrm{~m}$ x $18 \mathrm{~m}$ divided into two parts on each floor. The two parts of the ground floor were used as a restaurant and kitchen.

\section{(c) Character of loss}

The fire is thought to have originated in the timber floor above the restaurant. The fire spread to consume the contents of the room in the first floor and the upper part of the floor at that level and continued to spread to damage the second floor and roof above the affected area. There was no effective damage to the business parts of the premises but the major part of the building had been damaged severely. The fire occurred in February, a low period in the trade cycle.

(d) Recovery characteristics

Rather like the previous case study at the time of the study there had been no recovery for this particular business. The following list outlines some of the major features of this nonrecovery.

1. Partial help had been gained from the insurance company but their actions had been very slow. This resulted in most of the fire affected part of the building being severely damaged by water as during the two months following the fire heavy rains had fallen and no repairs to the roof had been carried out.

2. It seems that an architect has been appointed very soon after the fire but difficulties with payments and the arrangement of contractors had led to severe deterioration of the fire affected part of the building.

The delays in executing remedial work resulted in no trading being possible in the high part of the trade cycle of the year of the fire. It is estimated that recovery sufficient for continued operation of the restaurant could have been achieved in less than 1 month but all prospects for recovery were effectively lost because of the six months delay in agreeing a programme of work.

This particular company was a small family business and similar to the previous case study there were no links with large groups who could ensure supplies and loan money rapidly in advance of the insurance company's payments.

There was no contingency plan for such an event as the fire that occurred it would be difficult for any overall plan to have been developed at the stage of progress in this particular business. However, the owner could have helped himself a little by having proper records and complete inventories of stock held.

\section{Case study 8 - Public House}

(a) Nature of activity

The fire-hit premises was a licenced public house consisting of a public bar, lounge bar and a function room on the first floor. The public house was part of a large group which had at 
least 300 similar outlets. Although the premises were located in a built-up area of a city its business followed a trade cycle that had a peak between April and October.

(b) Nature of premises

The construction of the fire affected premises was of traditional brick and stone walls within reinforced concrete structure and a timber floor separated the two parts of the premises. Naturally the premises were fitted out in a traditional style for a public house with solid chairs and tables, bar fittings and carpetted floors.

\section{(c) Character of loss}

The fire occurred in late April. It began in the lounge bar and quickly spread throughout that area and extended to the function rooms above. The public bar, adjacent to the lounge bar on the ground floor, was affected mainly by heat and smoke but was fit to continue trading. With the exception of this latter space the whole premises were gutted internally, all furnishings and fittings destroyed although the basic construction and structure was unaffected. Immediately following the fire the premises were closed to enable restoration and refurbishment work to be carried out.

\section{(d) Recovery characteristics}

The public bar was re-opened within three weeks and six weeks after the fire the whole premises were re-opened. The recovery was organized within the group which had its own building section. This building section was used to re-fitting premises within a six week time scale no matter what part of the trade cycle. The staff employed was shuffled around other premises within the group for the time being and encouraged to take any holidays that were due to them at the time of the fire. Local custom was attracted back to the premises through advertising and no function trade was lost to the group because of their ability to re-schedule functions in other premises in the locality. The company had no formal contingency plan for postfire recovery, relying on the expertise of management to solve any problems. Another extremely important feature of recovery was that finance was available directly from the group. However, it should be noted that the insurance claim was not finalised until 15 months after the fire.

\section{Concluding remarks}

\section{Contingency plans}

In none of the case studies outlined was a formal contingency plan in existence. The successful recoveries emphasise the skill and flexibility of the management team. Flexibility of space-use was also an important feature in two cases - fibreboard manufacture and the foundry. In each case this flexibility was fortuitous as neither company would have planned for space in the production areas to have been kept idle as a contingency.

An important feature of contingency plans in commerce and industry is to ensure the security of documents and records. In all cases, except perhaps the public house, no special 
protection or duplication of essential records was practiced and in one case this gave rise to anxiety because of increased product liability and in another case eliminated all proof of purchase of supplies. Both of these features could give rise to heavy consequential losses.

In common with the findings of an earlier study (Marchant and Henesy, 1979) none of the companies had made an adequate fire loss evaluation of its activities. For example in the woodfibre board factory the basic lack compartmentation was made clear only after the fire when 30 doorways were closed-up. Poor attention to constructional details in the Hotel case was likely to have been a major factor in the extent of the spread of the fire. However a pre-fire evaluation of the building may have reduced the amount of damage in only two of the eight cases.

Contingency plans for continued trading after a fire would have helped recovery in only two of the cases - the hotel and restaurant. These two businesses are in private ownership and their fires resulted in a complete loss of trading capacity and this loss is likely to be permanent. Attention to detailed management aspects of post-fire recovery may have been helpful to these two businesses and may have made the road to recovery smoother for most of the other businesses.

\section{Role of the insurance company}

In only three cases were the insurance companies of positive assistance. The computer suite recovery was possible only because of the rapid agreement of three insurance companies on the actions to be taken. The fibre board manufacturer that maintained good relations with his insurer, and the foundry where the insurance company paid installments at the appropriate times.

The other three successful recoveries needed the technical and financial resources of their own groups to make a speedy recovery - the insurers being slow to respond.

The two cases where the business is likely not to recover had no strong technical or financial backing and it appears that the insurance companies were not able to help in assisting a speedy recovery. This inability to help is likely to lead to a complete loss of assets, except the value of the ground on which the buildings stand. This situation is not only likely to lead to a loss of prospects for a small number of people but a loss of revenue taxes to the nation. Small businesses therefore become vulnerable to fire loss and the proposition that a feasibility study of the creation of a self-financing advisory service should be carried out (Home Office, 1980) should be pursued vigorously.

\section{Direct and consequential losses}

In the first case study it is probable that no consequential loss was suffered because of the rapid action of insurance companies, fire brigade, and specialist reconditioning of computer equipment. The second case study indicated a consequential gain because of a fortuitous upturn in market demand. A situation similar to that described by Sharrock, 1975. Of the remaining six case studies some costs are available for four and are tabulated below. 
Table 9: Direct and consequential loss

\begin{tabular}{lccc}
\hline Case study & $\begin{array}{c}\text { Direct loss } \\
\text { (D) }\end{array}$ & $\begin{array}{c}\text { Consequential loss } \\
\text { (C) }\end{array}$ & $\begin{array}{c}\text { Ratio } \\
\text { C/D }\end{array}$ \\
\hline 4. Distillery & $\mathfrak{E} 5,000$ & 0 & 0 \\
5. Foundry & $\mathfrak{E} 37,000$ & $\mathfrak{1} 82,600$ & 2.4 \\
6. Hotel & $\mathfrak{E} 300,000$ & Business failure & Infinity \\
7. Restaurant & $\mathfrak{E} 58,000$ & Business failure & Infinity \\
\hline
\end{tabular}

The rate of direct to consequential loss has been reviewed elsewhere and ranges of values between 1.4 and 4 (Home Office, 1980) and 2 and 20 (Marchant and Henesy, 1979) have been described. It is clear from this study and the previous studies that this ratio cannot be predicted because it is a function of many variables and only analyses of individual components can provide estimates of potential direct and consequential losses.

Finally, it is clear that planning for potential business interruption that can be caused by fire is important, especially for the small business. Advice is needed primarily on the managerial aspects of loss prevention. Especially on the relationships of the expertise available from the professional people that are likely to be involved in post-fire recovery. Naturally the maintenance of proper records is essential for the individual company. Advice on the problems of plant and machinery replacement do not appear to be critical if a loss conscious management is responsible for the operation of the company. Advice on the fire control capabilities of buildings would seem to be needed by most managements and it is clear that buildings operated with a Fire Certificate and proper insurance cover can still contribute to excessive loss.

"Forget about causes and instead ask what should be done differently in the future". (Kletz, 1983).

\section{Aknowledgements}

Case stùdies 3-8 are summaries of case work undertaken by K.J. Maynes Esq., and were presented in 1983 as part fulfillment of the requirements for the M.Sc. degree in Fire Engineering to the University of Edinburgh.

\section{REFERENCES}

ANON (1984): "Loss control strategies", Foresight, Vol. IX, No 8, Feb. 84.

AQUA GROUP (1984): "Fire and building", Granada Publishing Ltd., London.

BANNISTER, J.E. (1976): in "Introduction to risk management in action", (ed. C.F. Best) Keith Shipton Developments Ltd., London, p. 3. 
BAWCUTT, P. A. (1982): "Earnings, risk management and contingency planning", Foresight, Vol. VII, No. 8, Feb. 82, pp. 4-11.

DAMICO, J.A. (1983): "Business interruption and manufacturing", Foresight, Vol. IX, No. 3, Sept. 1983, pp. 30-31.

FLETCHER, J.A. and DOUGLAS, H.M. (1971): "Total loss control", Associated Business Programmes London. (a) p. 132; (b) p. 69; (c) p. 75.

HALLER, M.G. (1977): "The aim of risk management" in "Paper in Risk Management, No. 7 'Approaches to Risk Management"' Keith Shipton Developments Ltd., London, pp. 12-23.

HOME OFFICE (1980): "Review of fire policy", Home Office, London.e (a) p. 67; (b) p. 69; (c) p. 417.

KALT, J. (1984) : "Brandschutzkonzept eines Industriebetriebes". Proceedings of BVD Seminar on Fire prevention Concepts, Vol. 3" BVD, Zurich, March 1984.

KINGSTON, M.D., HESKETH, L., PEAKER, A. and WARREN, D.J. (1977): "Investigation of consequential losses to the economy from fires in industry, the services sector and commerce". The Home Office, London.

KLETZ, T.A.: "After the investigation of the fire", Fire Prevention, No. 162, Sept. 1983, pp. 16-19.

LARSEN, A.L. (1984): "Small fire - great effect", Proceedings of BVD Seminar on Fire Prevention Concepts, Vol. 2, BVD Zurich, March 1984.

LEES, F. P. (1980/1983): "Loss prevention in the process industries", Vol. 1 and Vol. 2 Butterworths, London. (a) p. 8; (b) p. 69.

MARCHANT, E.W. (1984): "Fire safety and the facilities manager", Facilities, Vol. 2, No. 8, August 1984, pp. 7-13.

MARCHANT, E.W. and HENESY, C.J. (1979/1980): "Recovery from the effects of fire in industry", Fire Safety Journal, Vol. 2 (1979/1980), pp. 111-118.

MAYNES, K.J. (1983): "Post-fire recovery in business: actual or potential", M.Sc. Disertation, University of Edinburgh.

de MOULINS, P. (1984): “L'entrepreneur confronté à l'auto-responsabilité et à la loi", Proceedings of BVD Seminar on Fire Prevention Concepts, Vol. 1, BVD, Zurich, March 1984.

SHARROCK, P. (1975): "Cause and effects of fire in a petrochemical plant", Fire Prevention, No 110 , August 1975, pp. 35-38.

WOOLHEAD, F.E. (1976?): "Fire loss management" in "Handbook of Industrial Fire Protection and Security", Trade and Technical Press Ltd., Surrey, pp. 71-80.

WOOLHEAD, F.E. (1984): Unpublished paper to IFE Cumbria Branch Conference, April 1984. 